\title{
Brachystelma mahendragiriense (Apocynaceae), a new species from Odisha, India
}

\author{
K. Prasad ${ }^{1}$, A. Chorghe 2 , S. Surveswaran ${ }^{3}$ and P. Venu** \\ ${ }^{1}$ Central National Herbarium, Botanical Survey of India, Botanic Garden P.O., Howrah - 711103, \\ West Bengal, India. \\ ${ }^{2}$ Botanical Survey of India, Western Regional Centre, 7, Koregaon Road, Pune - 411001, Maharashtra, India. \\ ${ }^{3}$ Centre for Ecological Sciences, Indian Institute of Science, Bangalore - 560012, Karnataka, India. \\ ${ }^{4}$ Environment Protection Training and Research Institute, Gachibowli, Hyderabad - 500032, Telangana, India. \\ *E-mail: pvenu.bsi@gmail.com
}

\begin{abstract}
A tuberous herb with yellow flowers collected from the grassy slopes of the Mahendragiri hills (Odisha, India) is described as a new species of Brachystelma. Morphological and molecular data are furnished in support of this novelty.
\end{abstract}

Keywords: Asclepiadoideae, Brachystelma mahajanii, Ceropegia, Ceropegieae, Phylogenetic Tree, Tuberous Species

\section{Introduction}

Brachystelma R. Br. comprises of c. 160 species has distribution in sub-Saharan Africa, India, Sri Lanka, Southeast Asia and northern Australia (Prasad et al., 2016). All 27 species reported from India (20 from peninsular India), are hitherto known only from India (Kambale et al., 2014; Venu \& Prasad, 2015; Britto \& Bruyns, 2016; Prasad \& Prasanna, 2016; Prasad et al., 2016). The genus is represented by nine species in the Eastern Ghats. The authors while exploring open grassy slopes of Mahendragiri hills (Odisha), the northern stretch of Eastern Ghats, collected a tuberous herb with yellow flowers. It is described here as Brachystelma mahendragiriense sp. nov. The article draws significance for being the first report of presenting a Brachystelma species from the state of Odisha.

\section{Taxonomy}

Brachystelma mahendragiriense K. Prasad, Chorghe \& Venu, sp. nov.

Fig. 1

Type: INDIA, Odisha: Gajapati district, Mahendragiri hills, $18^{\circ} 58^{\prime} 05.3^{\prime \prime} \mathrm{N}, 084^{\circ} 22^{\prime} 08.6^{\prime \prime} \mathrm{E}$, 1393 m, 17.9.2014, K. Prasad \& Alok Chorghe 4221a (holo, CAL), 4221b-d (iso, BSID).

Herb, c. $20 \mathrm{~cm}$ high, perennial; tubers subglobose, c. $3 \mathrm{~cm}$ diam., pale brown. Stems erect, unbranched, c. $1.5 \mathrm{~mm}$ thick, pubescent when young, glabrescent on maturity; internodes c. $4 \mathrm{~cm}$ long. Leaves opposite-decussate, sessile, linear or linear-lanceolate, 3-6.5 $\times 0.15-0.2 \mathrm{~cm}$, margins bent inward, apex acute; margins and midrib puberulent. Inflorescences cymes, reduced to two flowers; bract 1, ovate-lanceolate, 1-1.1 mm long, apex acute, glabrous, greenish pink, caducous; bracteoles 2, linear, c. $0.5 \mathrm{~mm}$ long, apex obtuse, glabrous. Flowers upright, on 4-6 mm long pedicels, patent. Sepals 5, triangular-acuminate, $0.9-1.25 \mathrm{~mm}$ long, sparsely ciliate, apex acute or obtuse visible between corolla lobes, greenish pink. Corolla rotate, glabrous, yellow, mottled dull/bright pink at base; tube shallow, $0.5-0.75 \mathrm{~mm}$ long, mottled pink; lobes rotate, oblong-ovate, $3.5-4 \times 1.4-1.7 \mathrm{~mm}$, margins slightly recurved, apex mucronate with a translucent mucro. Corona biseriate, fused, cupular, $0.5-0.75 \times 1.5-1.75 \mathrm{~mm}$, exceeding gynostegium in length, blackish yellow, 5-lobed; upper margins undulate or obscurely 5-lobed, adaxially with horizontally spreading white trichomes in 10 clusters altogether; staminal corona lobes reduced to scales; anther appendages procumbent on stigma head, oblong, c. $4 \mathrm{~mm}$ long, apex obtuse, yellowish. Pollinia ovoid, $0.2-0.25 \times 0.1-1.5 \mathrm{~mm}$, yellow with pellucid margin along inner side, attached to brown corpusculum by short caudicle. Follicles in pairs or solitary, tapering towards apex, 6-8 cm long; seeds comose, narrowly elliptic, c. $4 \times 2 \mathrm{~mm}$, light brown at centre.

Flowering \& fruiting: May-September.

Habitat: Grass dominated rocky areas, 1350-1400 m. 


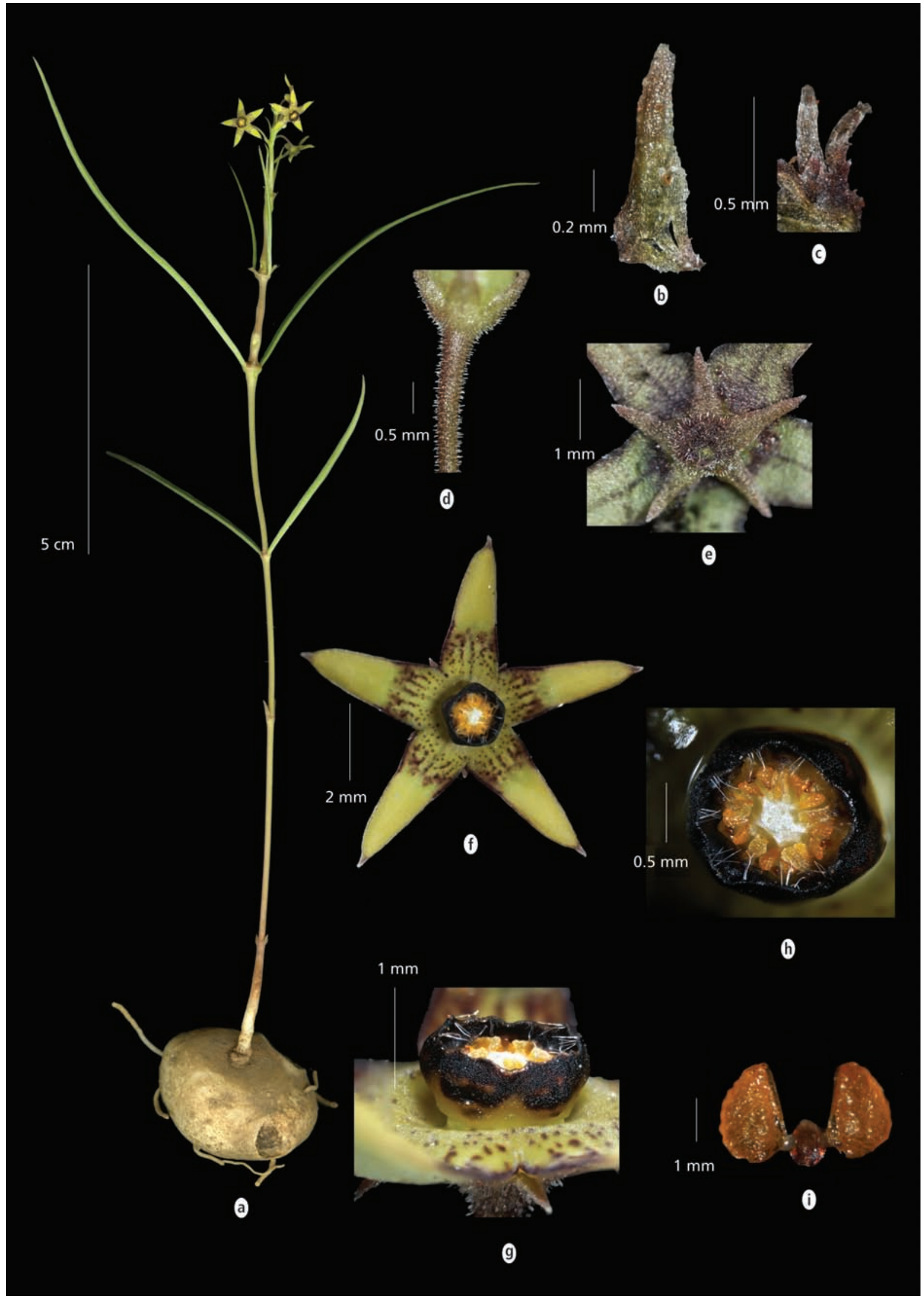

Fig. 1. Brachystelma mahendragiriense K. Prasad, Chorghe \& Venu: a. Habit; b. Bract; c. Bracteoles; d. Pedicel; e. Calyx; f. Corolla; g,h. Corona side/top views; i. Pollinarium. 
Distribution: Known from the type locality, Mahendragiri hills, Gajapati district, Odisha, India.

Etymology: The new species is named after Mahendragiri hills, its type locality.

Conservation Status: Since not much is known about its population and the species is described based on single location collections, this species is placed under 'Data Deficient' (DD) category (IUCN, 2014).

Recognition: Since the present collection is an erect species, the known climbers in Brachystelma and also species that produce flowers with slender corolla lobes and tips united at bud or even in flowering stage were considered remote for comparison. All the known erect Brachystelma species that produce flowers with indistinct corolla tube and lobes shorter ( $<5 \mathrm{~mm}$ long), fleshy and rotate, were closely examined with reference to material under report for novelty evaluation. All such species as well were found to have their own distinctiveness in some important features: Brachystelma matthewianum Bruyns \& Britto (deeply indented outer corona) and B. saldanhae Bruyns \& Britto (corona raised on a short stipe) from Tamil Nadu; B. vartakii Kambale \& S.R. Yadav (densely ciliated corolla lobes with bilobuled corona) from Kerala; B. swarupa Kishore \& Goyder (dangling inflorescence with 20 or more flowers at each node and corona cup ridged/grooved alternately at base and groves hairy outside) from Tamil Nadu and Kerala; B. annamacharyae K. Prasad et al. (corolla entirely hairy and lobes reflexed), $B$. ciliatum Arekal \& T.M. Ramakrishna (corolla lobes ciliated at tips and entirely reflexed on maturity; the latter feature is seen even in B. swarupa), B. glabrum Hook.f. (umbels terminal, 4-flowered, corolla lobes puberulous) from Andhra Pradesh and B. elenaduense Sathyan. (corolla lobes lanceolate and tips reflexed) from Karnataka are not similar to the proposed new species. Brachystelma mahajanii Kambale \& S.R. Yadav that has been reported from Nilgiris appears to have broad similarity with $B$. mahendragiriense but differs from it in certain characters as given below.

Brachystelma mahendragiriense is similar to B. mahajanii, but differs in plants attaining $20 \mathrm{~cm}$ height (vs. reach up to $10 \mathrm{~cm}$ in B. mahajanii); tubers subglobose (vs. tubers discoid in B. mahajanii) leaves never reflexed, margins bent inward (vs. leaves reflexed, margins flat in B. mahajanii) inflorescences 2-flowered at every node, upright (vs. 1-8-flowered, drooping in B. mahajanii); bract glabrous, greenish pink, caducous; (vs. bract green, hairy at tip, persistent in B. mahajanii); sepals triangular-acuminate (sepals subulate in B. mahajanii); corolla lobes oblong-ovate, yellow, mottled dull/bright pink at base, uniformly thick, apex ending into a translucent appendage (vs. lobes ovate, yellow but green at base, broad gibbous base distinct from linear thicker upper half, apex acute and devoid of translucent appendage in B. mahajanii); coronal cup blackish yellow, margins wavy with obscure lobation and with spreading white trichomes at interstaminal positions (corona greenish yellow, blotched purple inside and outside, margins distinctly 5-lobed, glabrous in B. mahajanii).

\section{Molecular studies}

Since the campanulate/rotate nature of the corolla in Brachystelma has evolved multiple times (Surveswaran et al., 2009; Bruyns et al., 2015) within the lineage of Ceropegia/Brachystelma, the authors intend to test the phylogenetic affinity of this new species. Molecular data from both chloroplast and nuclear genomes are used for construction of a phylogenetic tree.

\section{Materials and Methods}

Leaf material was collected in the field and stored in ziplock pouches along with silica gel which acts as an effective desiccant. Dried leaf material was ground in a plastic pestle in a $1.5 \mathrm{ml}$ eppendorf tube along with acid washed sand. DNA was extracted from the leaf material using Nucleospin plant II DNA extraction kit (Macherey-Nagel, Duren, Germany) according to the manufacturer's instructions. Two nuclear and two chloroplast DNA markers were used in this study. The DNA regions, primers and annealing temperatures are listed in Table 1.

\section{PCR amplification}

Polymerase chain reaction (PCR) amplifications of targeted regions was done in $25 \mu$ l volume reactions consisting for $2 \times$ DreamTaq Green PCR Master Mix (Thermo Scientific, Waltham, MA, USA), 10 pmol/ $\mu$ concentration of each primer and DNA template of about 1-100 ng. The PCR cycle consisted of an initial denaturation at $95^{\circ} \mathrm{C}$ for 2 minutes followed by 40 cycles each of $95^{\circ} \mathrm{C}$ for 15 seconds, $58^{\circ} \mathrm{C}$ (annealing) for 15 seconds and $72^{\circ} \mathrm{C}$ (extension) for 55 seconds. A final extension at $72^{\circ} \mathrm{C}$ was done for 5 minutes. The annealing temperature of $58^{\circ} \mathrm{C}$ was maintained for ITS, trnL intron + trnL-trnF spacer and trnS-trnG spacer. For NCPGS region an annealing temperature of $46^{\circ} \mathrm{C}$ was used.

PCR products were visualized on $1 \%$ agarose gels stained with Ethidium Bromide. The PCR products were enzymatically cleaned using ExoSAP-IT (Affymetrix, Santa Clara, CA, USA). $2 \mu \mathrm{l}$ of ExoSAP-IT was added to $20 \mu \mathrm{l}$ of PCR product and incubated at $37^{\circ} \mathrm{C}$ for 45 minutes. The 
Table 1. DNA markers and primers used in phylogeny and annealing temperatures for PCR

\begin{tabular}{|c|c|c|c|c|c|}
\hline Marker & Gene name & Genome & $\begin{array}{l}\text { Primer Forward/ } \\
\text { Reverse }\end{array}$ & $\begin{array}{l}\text { Annealing } \\
\text { temperature }\end{array}$ & Reference \\
\hline ITS & $\begin{array}{l}\text { Internal transcribed } \\
\text { spacer }\end{array}$ & Nuclear & ITS4, ITS5 & $58^{\circ} \mathrm{C}$ & $\begin{array}{l}\text { White et al., } \\
1990\end{array}$ \\
\hline nCPGS & $\begin{array}{l}\text { Intron of Nuclear } \\
\text { encoded chloroplast } \\
\text { glutamine synthase }\end{array}$ & Nuclear & $\begin{array}{l}\text { GScp687f, } \\
\text { GScp994r }\end{array}$ & $46^{\circ} \mathrm{C}$ & $\begin{array}{l}\text { Emshwiller } \\
\text { \& Doyle, } \\
1999\end{array}$ \\
\hline $\operatorname{trn} L+\operatorname{trn} L-F$ & $\begin{array}{l}\text { trnL intron and } \\
\text { trnL-trnF intergenic } \\
\text { spacer }\end{array}$ & Chloroplast & $c, f$ & $58^{\circ} \mathrm{C}$ & $\begin{array}{l}\text { Taberlet et al., } \\
1991\end{array}$ \\
\hline $\operatorname{trn} S-G$ & $\begin{array}{l}\text { trnS-trnG intergenic } \\
\text { spacer }\end{array}$ & Chloroplast & $\begin{array}{l}\operatorname{trn} S(G C U), \operatorname{trn} \\
\text { G (UCC) }\end{array}$ & $58^{\circ} \mathrm{C}$ & $\begin{array}{l}\text { Hamilton, } \\
1999\end{array}$ \\
\hline
\end{tabular}

ExoSAP-IT activity was stopped by incubating at $80^{\circ} \mathrm{C}$ for 15 minutes. The purified PCR products were sequenced on both strands using the forward and reverse primer on an ABI Prism 3100 DNA sequencer in National Centre for Biological Sciences (Bangalore, India).

\section{Sequence assembly and Phylogenetic analysis}

Forward and reverse sequences were assembled using the pregap4 and gap4 modules of the Staden package ver. 2.0.0b10 (Staden et al., 2000). Sequences of other Brachystelma and Ceropegia were downloaded as FASTA files from the Genbank database. Sequence assembly was performed using the Muscle algorithm using Seaview ver. 4.4.2 (Gouy et al., 2010). Sequence editing was performed using Aliview ver. 1.17 (Larsson, 2014).

Maximum parsimony analysis was performed using PAUP $^{*} 4.0$ b10 (Swofford, 2003). The four datasets were combined and tested for homogeneity using the partition homogeneity test. Heuristic searches were performed using the tree bisection reconnection (TBR) branch swapping, random addition of sequences and multiple trees option. Bootstrap supports were inferred from 1000 replicates using a heuristic search with the same settings as above. The best-fit model of sequence evolution for each dataset was computed using jModelTest ver. 2.1.7 (Darriba et al., 2012). Bayesian phylogenetic analysis was performed using MrBayes ver. 3.2.2 (Ronquist et al., 2012). The separate models were applied to each partition. Two independent Metropolis coupled Markov chain Monte Carlo chains were for 20 million generations sampling every 1000 generations. The convergence of the runs were checked using
Tracer ver. 1.6 (Rambaut et al., 2014) as the values of effective sample size (ESS) greater than 200. The first $25 \%$ of the trees were considered as the burnin and the remaining 75\% were summarized in MrBayes.

\section{Results and Discussion}

The total length of the DNA data set and individual datasets, their variability, parsimony informative sites and best-fit DNA sequence evolution models are summarized in Table 2 . The heuristic search for the most parsimonious trees yielded two trees with a length of 170 steps, consistency index (CI) of 0.912 and a retention index (RI) of 0.914. The topology of the trees was highly congruent and one of the two trees is shown on Figure 2. The Bayesian phylogenetic tree also yielded a similar tree topology but with some incongruent nodes which were not well supported (Bayesian posterior probability $\geq 0.95$ and Maximum parsimony bootstrap greater than $90 \%$ were considered strong support). The new species was found closely associated with B. mahajanii. However, this sister relationship is not well supported because of the lack of sequence variation (pair wise genetic distance (p-distance) of 0.00073 .

Overall, B. mahendragiriense falls in a clade containing most of the Indian Brachystelmas including B. mahanjanii, B. ciliatum, B. kolarense Arekal \& T.M. Ramakrishna, B. vartakii and B. edule Collett \& Hemsl. complex (B. edule, B. malwanense S.R. Yadav \& N.P. Singh and B. naorojii P. Tetali et al.). All these taxa are sister to B. brevitubulatum (Bedd.) Gamble. Brachystelma bourneae Gamble, however, appears as a separate lineage of Brachystelma and is not closely sister to this clade. 
Table 2. Sequence characteristic of the nucleotide markers used in phylogeny

\begin{tabular}{lcccl}
\hline Marker & Total & $\begin{array}{l}\text { Variable/ } \\
\text { non-phylogenetically } \\
\text { informative characters }\end{array}$ & $\begin{array}{l}\text { Phylogenetically } \\
\text { informative } \\
\text { Characters (PIC) }\end{array}$ & $\begin{array}{l}\text { Best-fit model of } \\
\text { sequence evolution }\end{array}$ \\
\hline ITS & 633 & 27 & 28 & SYM+G \\
nCPGS & 864 & 43 & 19 & HKY \\
trnL+trnLF & 818 & 6 & 7 & GTR \\
trnSG & 558 & 14 & 4 & F81 \\
Total & 2873 & 90 & 58 & GTR+I \\
\hline
\end{tabular}

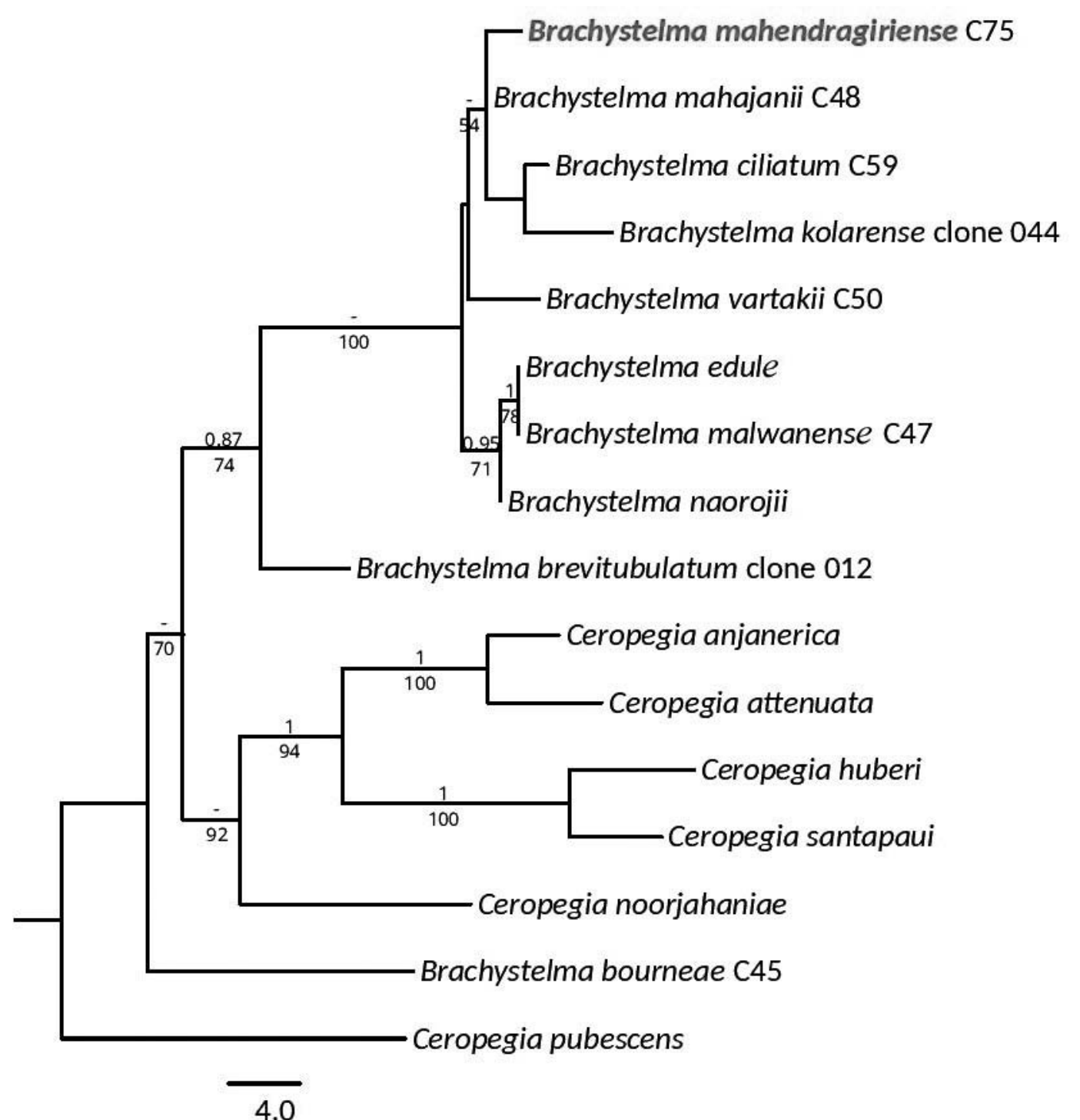

Fig. 2. One of the two most parsimonious trees obtained from a heuristic search in PAUP*. The numbers above branches indicate Bayesian posterior probability support and the number below branches indicate bootstrap support percentages under parsimony method. Scale bar indicates numbers of nucleotide changes per 100 sites. 


\section{Acknowledgements}

The authors thank the Director, Botanical Survey of India, for facilities. Drs. Prasad and Venu also thank SERB-DST, New Delhi and CSIR, New Delhi, respectively, for the financial support. They also thank their colleagues at DRC, BSI, Hyderabad, for encouragement and support.

\section{Literature Cited}

Britto, S.J. \& P.V. Bruyns 2016. Three new species of Brachystelma from Tamil Nadu, India. Haseltonia 22: 48-54.

Bruyns, P.V., Klak, C. \& P. Hanacek 2015. Recent radiation of Brachystelma and Ceropegia (Apocynaceae) across the Old World against a background of climatic change. Molec. Phylogen. Evol. 90: 49-66.

Darriba, D., Taboada, G.L., Doallo, R. \& D. Posada 2012. jModelTest 2: more models, new heuristics and parallel computing. Nature, Meth. 9(8): 772-772.

Edgar, R.C. 2004. MUSCLE: multiple sequence alignment with high accuracy and high throughput. Nucl. Acids Res. 32(5): 1792-1797.

Emshwiller, E. \& J.J. Doyle 1999. Chloroplastexpressed glutamine synthetase (ncpGS): potential utility for phylogenetic studies with an example from Oxalis (Oxalidaceae). Molec. Phylogen. Evol. 12(3): 310-319.

Gouy, M., Guindon, S. \& O. Gascuel 2010. SeaView version 4: a multiplatform graphical user interface for sequence alignment and phylogenetic tree building. Molec. Biol. Evol. 27(2): 221-224.

Hamilton, M.B. 1999. Four primer pairs for the amplification of chloroplast intergenic regions with intraspecific variation. Molec. Ecol. 8: 521-523.

IUCN Standards and Petitions Subcommittee 2014. Guidelines for using the IUCN Red List Categories and Criteria, Version 11. Prepared by the Standards and Petitions Subcommittee of the IUCN Species Survival Commission. Available from: http://jriucnredlist.org/documents/ RedListGuidelines.pdf, accessed February 2014.

Kambale, S.S., Surveswaran, S. \& S.R. Yadav 2014. Two new species of Brachystelma Sims (Apocynaceae: Asclepiadoideae-Ceropegieae) from the Western Ghats of India. Kew Bull. 69: 9493(1-10).

Larsson, A. 2014. AliView: a fast and lightweight alignment viewer and editor for large datasets. Bioinformatics 30(22): 3276-3278.
Prasad, K. \& P.V. Prasanna 2016. Brachystelma seshachalamense (Apocynaceae), a new species from Andhra Pradesh, India. Bangladesh J. Pl. Taxon. 23(1): 53-57.

Prasad, K., Prasanna, P.V., Meve, U., Sankara Rao, M. \& T. Thulasaiah 2016. Brachystelma annamacharyae sp. nov. (Apocynaceae) from the Seshachalam hills of Andhra Pradesh (India). Nordic J. Bot. 34: 360-363.

Rambaut, A., Suchard, M.A., Xie, D. \& A.J. Drummond 2014. Tracer v1. 6. Computer program and documentation distributed by the author, website http://beast. bio. ed. ac. uk/Tracer (accessed 27 July 2014).

Ronquist, F. \& J.P. Huelsenbeck 2003. MrBayes 3: Bayesian phylogenetic inference under mixed models. Bioinformatics 19(12): 1572-1574.

Ronquist, F., Teslenko, M., Mark, P. van der, Ayres, D.L., Darling, A., Hohna, S., Larget, B., Liu, L., Suchard, M.A. \& J.P. Huelsenbeck 2012. MrBayes 3.2: efficient Bayesian phylogenetic inference and model choice across a large model space. Syst. Biol. 61(3): 539-542.

Staden, R., Beal, K.F. \& J.K. Bonfield 2000. The Staden package, 1998. Methods Molec. Biol. (Clifton, NJ), 132, 115.

Surveswaran, S., Kamble, M.Y., Yadav, S.R. \& M. Sun 2009. Molecular phylogeny of Ceropegia (Asclepiadoideae, Apocynaceae) from Indian Western Ghats. Pl. Syst. Evol. 281(1-4): 51-63.

Swofford, D.L. 2003. PAUP*: Phylogenetic analysis using parsimony, version $4.0 \mathrm{~b} 10$.

Taberlet, P., Gielly, L., Pautou, G. \& J. Bouvet 1991. Universal primers for amplification of three non-coding regions of chloroplast DNA. Pl. Molec. Biol. 17(5): 1105-1109.

The Plant List, 2010. Version 1. Published on the Internet; http://www.theplantlist.org/ (accessed 10th April, 2013).

Venu, P. \& K. Prasad 2015. The existential crisis in Indian Brachystelma (Apocynaceae). Curr. Sci. 109(4): 680-682.

White, T.J., Bruns, T., Lee, S.J.W.T. \& J.W. Taylor 1990. Amplification and direct sequencing of fungal ribosomal RNA genes for phylogenetics. PCR Protocols: A guide to methods and applications 18: 315-322.

Received: 7.9.2016

Revised and Accepted: 8.11.2017 